\title{
Applications of calcium and boron increase yields of Italian tomato hybrids (Solanum lycopersicum) in two growing seasons
}

\section{Aplicaciones de calcio y boro aumentan la producción de híbridos de tomate Italiano (Solanum lycopersicum) en dos temporadas de cultivo}

DÉBORA T. ZAMBAN'

DAIANE PROCHNOW ${ }^{2}$

BRAULIO O. CARON'

MÔNICA TURCHETTO ${ }^{3}$

DANIELE CRISTINA FONTANA ${ }^{1,4}$

DENISE SCHMIDT ${ }^{1}$

Italian tomato fruits with symptoms of apical rot.

Photo: D.T. Zamban

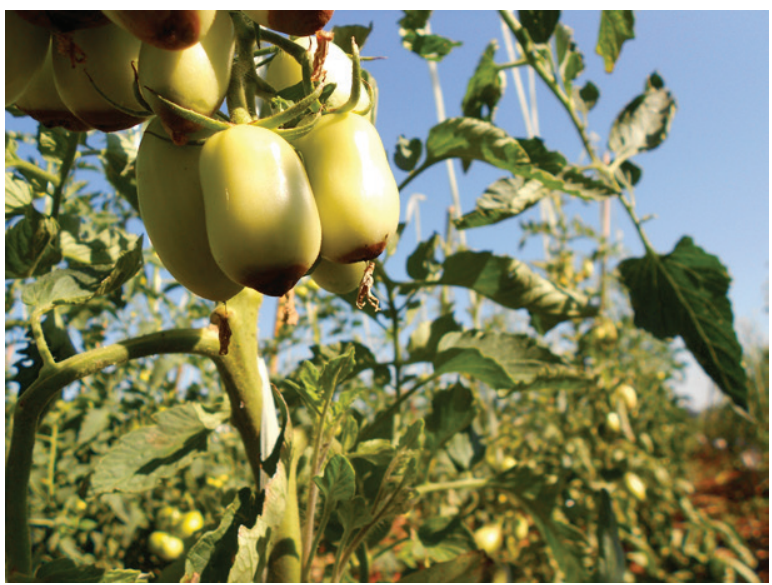

\begin{abstract}
The objective of this study was to evaluate the effect of boron soil treatments and the frequency of calcium applications on the flowering, agronomic performance, and incidence of blossom end rot in Italian tomato hybrids grown in conventional systems during two growing seasons. Two experiments were carried out in the experimental area of the Federal University of Santa Maria, Frederico Westphalen campus (Brazil) during 2012 and 2013. A randomized block experiment design was used in a $2 \times 2 \times 3 \times 3$ factorial scheme with two hybrids (San Vito and Netuno) in two growing seasons (Spring-Summer and Summer-Fall), three boron doses $(0.0,2.0$, or $4.0 \mathrm{~g} /$ hole), and three frequencies of calcium application (absence of application, weekly, or biweekly application) with four replicates. The seedlings were transplanted on September 4, 2012 for the Spring-Summer growing season and on January 26, 2013 for the Summer-Fall growing season. The Netuno hybrid was more productive in comparison to the San Vito hybrid, but more susceptible to blossom end rot. Both growing seasons can be recommended for Italian tomato production in Rio Grande do Sul although the Spring-Summer growing season was more productive than the Summer-Fall growing season. The biweekly application frequency of $0.6 \% \mathrm{CaCl}_{2}$ was the best option for fertilizer management, resulting in higher yields

Departament of Agronomic and Environmental Sciences, Campus of Frederico Westphalen, Federal University of Santa Maria, Frederico Westphalen-RS (Brazil). ORCID Zamban, D.T.: 0000-0003-1054-6472; ORCID Caron, B.O.: 0000-0002-6557-3294; ORCID Fontana, D.C.: 0000-0003-4285-6299; ORCID Schmidt, D.: 0000-0002-9963-4956

2 Department of Plant Science, Center of Genomics and Plant Breeding, Campus of Capão do Leão, Federal University of Pelotas, Capão do Leão-RS (Brazil). ORCID Prochnow, D.: 0000-0002-5109-5789

3 Department of Food Science and Technology, Federal University of Santa Maria, Frederico Westphalen-RS (Brazil). ORCID Turchetto, M.: 0000-0003-3672-5874

4 Corresponding author.daani_fontana@hotmail.com
\end{abstract}


and a lower number of fruits with an incidence of blossom end rot. The increment of the boron dose defined the higher number of fruits per plant and yield increase.

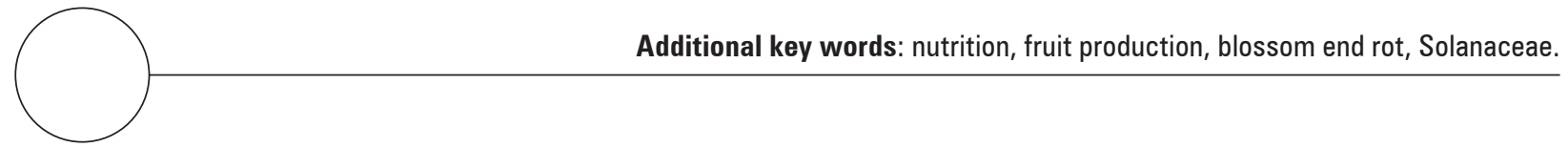

\section{RESUMEN}

El objetivo de este estudio fue evaluar el efecto de tratamientos de boro edáfico y frecuencia del calcio foliar en floración, sobre la producción y ocurrencia de la pudrición apical de híbridos de tomate italiano, cultivados en el sistema convencional en dos temporadas de cultivo. Se realizaron dos experimentos en el área experimental perteneciente a la Universidade Federal de Santa Maria, campus de Frederico Westphalen (Brasil), en los años 2012 y 2013. El diseño experimental fue de bloques al azar con un arreglo factorial $2 \times 2 \times 3 \times 3$ cuyo factores fueron dos híbridos (San Vito y Neptuno), en dos épocas de cultivo (primavera-verano y verano-otoño), tres dosis de boro (0; 2,0 y 4,0 $\mathrm{g} /$ planta) y tres frecuencias de aplicación de calcio (ausencia de aplicación, aplicación semanal y quincenal) y cuatro repeticiones. El trasplante de plántulas se realizó el día 04 de septiembre de 2012 para la primavera-verano y el 26 de enero para el verano-otoño. El híbrido Neptuno es más productivo en comparación con el híbrido San Vito, pero más susceptible a la pudrición apical. Las dos épocas de cultivo pueden ser recomendadas para el cultivo del tomate italiano en Rio Grande do Sul, aunque el cultivo de primavera-verano presenta mayor productividad cuando se compara al verano-otoño. La frecuencia de aplicación quincenal de $\mathrm{CaCl}_{2}$ al 0,6\% se constituye en la mejor opción de manejo de fertilización, en el sentido de obtener mayor productividad y menor número de frutos con incidencia de pudrición apical. El incremento de la dosis de boro condiciona mayor número de frutos por planta y aumento de la productividad.

Palabras clave adicionales: nutrición, rendimiento, pudrición apical, Solanaceae.

Received for publication: 03-07-2017 Accepted for publication: 30-01-2018

INTRODUCTION

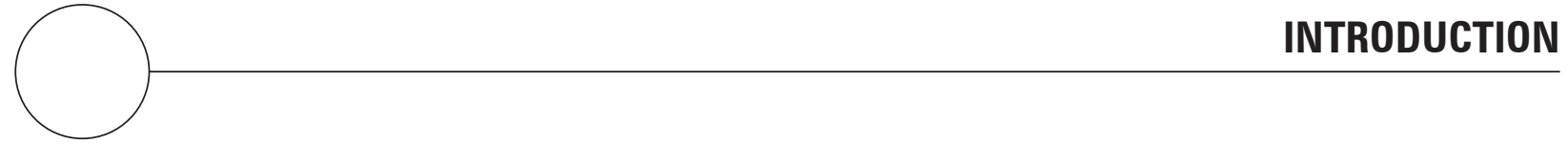

The tomato (Solanum lycopersicum) can be cultivated in different cropping systems in several geographic latitudes (Shirahige et al., 2010). The total cultivated area for tomato in Brazil was 55,000 ha in 2015, with the states of Goiás, Minas Gerais, and São Paulo being the largest national producers (MAPA, 2015). The tomato is a very significant crop for the Brazilian population because of its socioeconomic relevance (Schwarz et al., 2013), increasing consumption because of nutritional factors (Iglesias et al., 2015). Among the groups of tomato on the market, the commonly called 'Italian' type, also called the saladette tomato (Filgueira, 2000; Alvarenga, 2004), cultivations have been improving qualities associated with taste, resulting in greater versatility in culinary use (Shirahige et al., 2010).
A number of complex factors and biochemical pathways can influence tomato yields; for example, calcium deficiency can lead to blossom end rot, something that has caused preventable losses for growers. Calcium, upon incorporation into cellular tissue becomes immobile and, thus, there is a need for a constant supply in order to meet fruit growth requirements. Because of the low rate of translocation, the characteristic symptom of calcium deficiency first presents as flaccidity of the tissues at the apical part of immature fruits because of low calcium translocation, which often presents as a light brown irregular soft spot that becomes darker as the fruit grows. Calcium deficiency can also result in internal browning of the fruit (Bresolin et al., 2010). 
Plant genetic traits, with respect to the absorption and translocation of calcium to the fruits, also interfere in the occurrence of blossom end rot (Greenleaf and Adams, 1969). Certain cultivars or hybrids function better in calcium deficient environments, and, thus, care needs to be taken when deciding which cultivar will be planted (Giordano et al., 2005). Calcium applied to leaves is first transported by the phloem to new tissues and the flow is linked to the metabolic activity (Dechen and Nachtigall, 2007).

Calcium deficiencies have been studied jointly with boron deficiencies because of similarities of these elements in cell wall functions. According to Yamauchi et al. (1986), an absence of boron can decrease the calcium content in the pectin in the cell wall of tomato leaves. Boron deficiencies cause dark lesions and cleavages in fruits and result in a considerable depreciation in tomato yields (Malavolta et al., 1989). Furthermore, boron deficiencies reduce flowering and pollination because boron acts as a regulator in carbohydrate metabolism and translocation (Silva and Faria, 2004).

In southern Brazil, tomatoes are traditionally grown in the Spring when weather conditions are more suitable for the plants, and higher prices of this vegetable are seen during the Fall when greater difficulties for its cultivation are verified, such as low temperatures and less solar radiation than is needed by the crop.

The objective of this study was to evaluate the effect of boron doses applied to the soil and the effect of frequencies of floral calcium application on the agronomic performance and the incidence of blossom end rot in Italian tomato hybrids grown in conventional system in two growing seasons.

\section{MATERIALS AND METHODS}

Two experiments were carried out in the field from August, 2012 to May, 2013 in the experimental area of the Federal University of Santa Maria, Frederico Westphalen campus (Brazil), located at $27^{\circ} 23^{\prime} 48^{\prime \prime} \mathrm{S}$ and $53^{\circ} 25^{\prime} 45^{\prime \prime} \mathrm{W}$, at an altitude of $490 \mathrm{~m}$. According to the Köppen climate classification, the climate is subtropical humid (Alvares, 2014) and the predominant soil in the region is classified as typical aluminoferric red Oxisol (Embrapa, 2013).

The experiment design was a randomized block in a $2 \times 2 \times 3 \times 3$ factorial scheme with two hybrids in two growing seasons, three boron doses, and three frequencies of calcium application with four replicates. Each block was composed of four plants for the evaluation. The evaluated hybrids were San Vito and Netuno, both have indeterminate growth habits and belong to the Italian group cultivated in the Spring-Summer and Summer-Fall seasons. Three boron doses were applied to the soil $(0.0,2.0$, and $4.0 \mathrm{~g} /$ hole) and three frequencies of calcium were applied to the leaves or flowers (absence of application, weekly, and biweekly application).

The boron doses were applied to individual holes when the seedlings were planted. Treatments of $0.6 \%$ calcium chloride were applied with a manual sprayer directed at the floral structures; the procedure began during the anthesis period and was carried out until the end of fruiting.

The seedlings were produced in trays containing a commercial substrate, composed of sphagnum peat in a floating system. Soil preparation for plant cultivation was carried out in a conventional system, with plowing, harrowing, and subsequent formation of ridges. Basic and topdressing fertilization were done according to the results of soil analysis. The soil analysis indicated a $6.1 \mathrm{pH}$, and values for clay of $64 \%$, P of $6.7 \mathrm{mg} \mathrm{L}^{-1}$, K of $239.5 \mathrm{mg} \mathrm{L}^{-1}$, organic matter of $2.9 \%$, cation exchange capacity of 11.3 , Ca of $5.7 \mathrm{cmolc} \mathrm{L}^{-1}$, and B of $0.4 \mathrm{mg} \mathrm{L}^{-1}$. The seedlings were transplanted on September 4, 2012 for the first growing season and on January 26, 2013 for the second growing season when they presented approximately five leaves.

The plants were grown vertically with single-stem training by means of a ribbon, single row with spacing of $1.0 \mathrm{~m}$ between rows and $0.5 \mathrm{~m}$ between plants. Crop irrigation was performed with a drip system. A soil heaping procedure were carried out at $20 \mathrm{~d}$ after the transplant, jointly with the first topdressing fertilization, and the other fertilizations were performed at $10 \mathrm{~d}$ intervals. General cultivation practices recommended for the crop were carried out through removal of sprouts, plant tips, and bottom leaves. Control of invasive plants and phytosanitary treatments were carried out according to the technical recommendations for the crop.

Meteorological data concerning the two growing seasons were collected from an automatic station of the National Institute of Meteorology (INMET, Brazil) located approximately $300 \mathrm{~m}$ from the experimental 
site. It was possible to determine the air temperature and global solar radiation values.

The harvest started on November 16, 2012 for the first growing season and April 6, 2013 for the second growing season. The harvest point was characterized by the appearance of a red color on the fruits. The harvests were performed daily in order to assess the agronomic performance of the hybrids. The fruits of each plot were evaluated and the following variables were measured: total number of fruits (TNF), number of commercial fruits (NCF), number of non-commercial fruits (NNCF), number of fruits with blossom end rot (NFBER), mean weight of fruits (MWF), commercial fruit weight (CFW), non-commercial fruit weight (NCFW), fresh weight of fruits (FWF), commercial fruit yield (CFY), and mean fruit diameter (MFD).

The data were submitted to an analysis of variance. If significant, the means were compared by the Tukey test at $5 \%$ probability or submitted to a process of regression model adjustment according to the factor assessed by the statistical program SAS (SAS Institute, 2002).

\section{RESULTS}

The data on the temperature and incident global solar radiation recorded during the experiment are

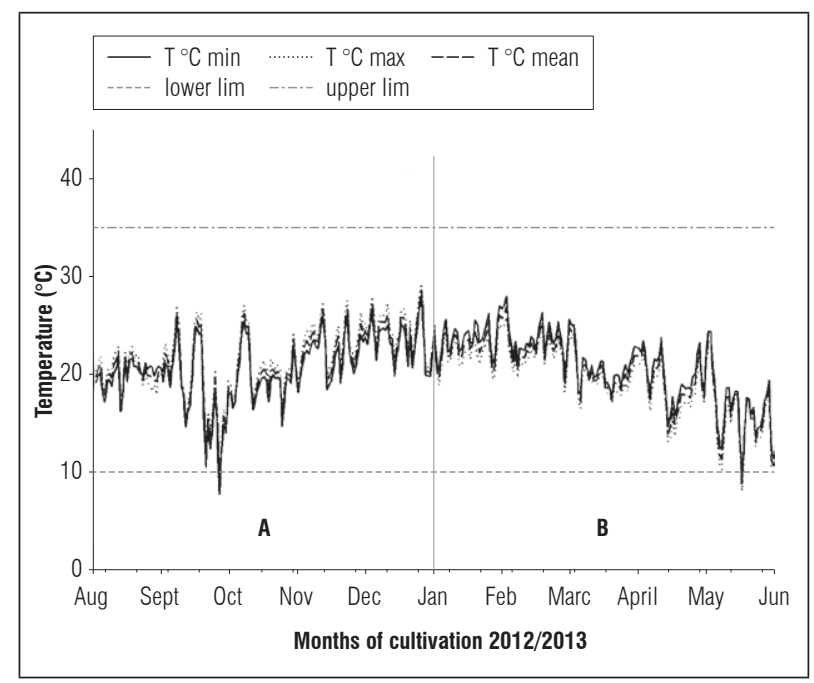

\footnotetext{
Figure 1. Mean of maximum, mean, and minimum air temperatures recorded during the growing seasons Spring-Summer (A) and Summer-Fall (B), lower limit and upper limit of temperatures during cultivation of Italian tomato hybrids.
}

shown in figures 1 and 2. The temperature during most of the crop period was tolerable for crop development, 10 to $35^{\circ} \mathrm{C}$ (Alvarenga, 2004). Temperatures below the tolerable level were recorded for crops at the beginning of the first growing season and from flowering stage until fruit maturation for the second growing season.

The observed incident global solar radiation ranged between a maximum value of $32.4 \mathrm{MJ} \mathrm{m}^{-2} \mathrm{~d}^{-1}$ and a minimum of $0.14 \mathrm{MJ} \mathrm{m}^{-2} \mathrm{~d}^{-1}$ for the first growing season and between the maximum value of $31.5 \mathrm{MJ} \mathrm{m}^{-2}$ $\mathrm{d}^{-1}$ with a minimum of $1.35 \mathrm{MJ} \mathrm{m}^{-2} \mathrm{~d}^{-1}$ for the second growing season (Fig. 2). In the Spring-Summer growing season, the solar radiation was lower at the beginning of the cycle, while in the Summer-Fall growing season, the solar radiation remained below the trophic limit for several days for the crop during periods of greater demand, such as flowering, fruiting, and fruit maturation.

For the total number of fruits, fresh weight of fruits, and commercial fruit yield, the analysis of variance showed interaction between the factors: hybrid $x$ boron doses, and hybrids $x$ frequency of calcium application. The mean fruit diameter exhibited significant effects for the factors of hybrid and frequencies of calcium application.

There were interactions between the growing seasons $\times$ frequency of calcium application and boron doses $\times$ frequency of calcium application for the

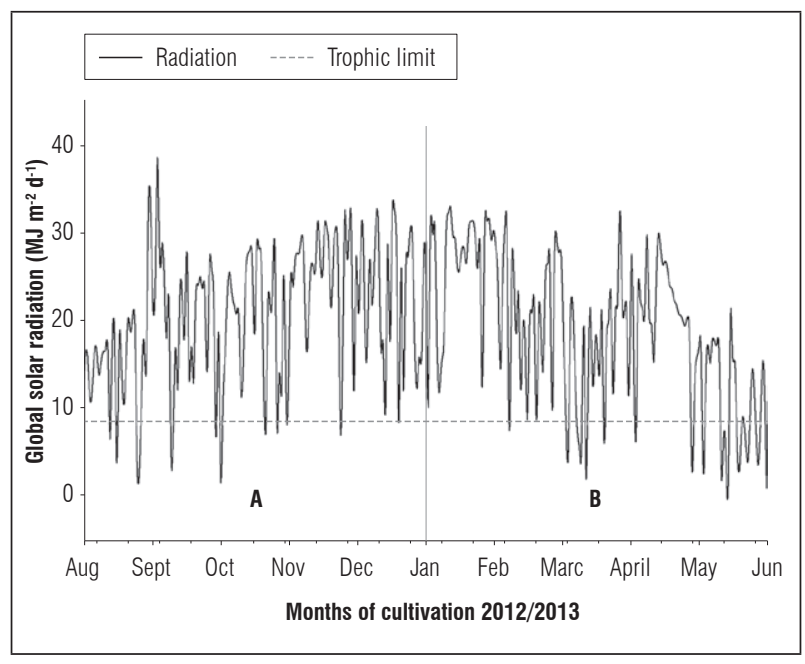

Figure 2. Mean of incident total solar radiation recorded during Spring-Summer (A) and Summer-Fall (B) during cultivation of the Italian tomato hybrids. 
number of the production of commercial fruits and fresh weight of fruits. For mean weight of fruits, the interaction was observed for the factors growing seasons $\times$ frequency of calcium application. For the number of non-commercial fruits, non-commercial fruit weight and number of fruits with blossom end rot, an analysis of variance showed interactions between the factors of growing seasons $x$ frequency of calcium application, hybrids $\times$ frequency of calcium application, and boron doses $\times$ frequency of calcium application.

The hybrid Netuno presented superior performance for the variables mean fruit diameter, fresh weight of fruit, total number of fruits, and commercial fruit yield when compared to the San Vito hybrid (Tab. 1). For the calcium application frequency, the biweekly application was similar to the weekly application, forming tomato fruits with a superior diameter (Tab. 2).

For the control treatment of frequency of application without calcium, the Spring-Summer growing season was superior to the Summer-Fall season for the variable mean weight of fruits (MWF), while the other frequencies presented similar performances in both growing seasons. The highest MWF was

\section{Table 1. Mean fruit diameter (MFD), fresh weight of fruits (FWF), number of commercial fruits (NCF), and commercial fruit yield (CFY) of the Italian tomato hybrids.}

\begin{tabular}{|c|c|c|c|c|}
\hline \multirow{2}{*}{ Hybrids } & \multicolumn{4}{|c|}{ Production parameters } \\
\cline { 2 - 5 } & $\begin{array}{c}\text { MFD } \\
\text { (cm) }\end{array}$ & $\begin{array}{c}\text { FWF } \\
\text { (g/fruit) }\end{array}$ & NCF/plant & $\begin{array}{c}\text { CFY } \\
\text { (kg/plant) }\end{array}$ \\
\hline Netuno & $4.8 \mathrm{a}$ & $99.6 \mathrm{a}$ & $19.0 \mathrm{a}$ & $1.9 \mathrm{a}$ \\
\hline San Vito & $4.3 \mathrm{~b}$ & $96.4 \mathrm{~b}$ & $16.1 \mathrm{~b}$ & $1.6 \mathrm{~b}$ \\
\hline CV (\%) & 5.94 & 6.74 & 14.03 & 14.61 \\
\hline
\end{tabular}

Means followed by the same letters in the column do not differ from each other according to the Tukey test $(P \leq 0.05)$.

Table 2. Mean fruit diameter ( $\mathrm{mm}$ ) of the Italian tomato hybrids as a function of the frequency of calcium application.

\begin{tabular}{|c|c|}
\hline Frequency of calcium application & MFD (mm) \\
\hline Without application & $44.6 \mathrm{~b}$ \\
\hline Biweekly & $46.3 \mathrm{a}$ \\
\hline Weekly & $45.2 \mathrm{ab}$ \\
\hline CV (\%) & 5.94 \\
\hline
\end{tabular}

Means followed by the same letters in the column do not differ from each other according to the Tukey test $(P \leq 0.05)$. observed with a biweekly application of calcium, which was not statistically different from weekly applications, and the lowest performance was verified in the absence of a calcium application (Tab. 3). For the Summer-Fall growing season, the highest MWF was verified in the biweekly and weekly frequencies of calcium application, which did not statistically differ from one another, and the lowest was verified in the absence of calcium application (Tab. 3).

For the variable commercial fruit weight (CFW), the weekly and biweekly applications provided superior performance in the Spring-Summer growing season. The greatest number of commercial fruits (NCF) and commercial fruit weight (CFW) were observed in the biweekly application of calcium, followed by the weekly application. Without calcium applications, for the variable non-commercial fruit weight (NCFW), there was a greater production of NCFW in the Spring-Summer season when compared to the Summer-Fall growing season. Lower production was observed for the biweekly application of calcium as well as the Summer-Fall growing season where greater NCFW occurred in the absence of calcium applications (Tab. 3).

For the total number of fruits per plant (TNF) as a function of frequency of calcium application, the highest TNF for the growing season was recorded for both the biweekly and weekly applications, differing from the absence of application during the Spring-Summer growing season. For the Summer-Fall season, the TNF/plant was similar to the weekly and biweekly applications, which did not statistically differ from each other and presented a lower TNF without calcium applications (Tab. 3).

The number of fruits with blossom end rot (NFBER) was greater in the Spring-Summer growing season for the treatment without calcium and weekly applications of calcium. The greatest NFBER were observed in the absence of calcium applications for both growing seasons. For the Spring-Summer growing season, the lowest number was observed in biweekly applications, differing statistically from the others. The weekly and biweekly frequencies did not differ for the Summer-Fall growing season (Tab. 3).

For the tested hybrids, Netuno performed better respective to the frequencies of biweekly and weekly calcium applications for the number of fruits per plant (TNF). The lowest TNF was observed in the absence of calcium application, differing statistically 
Table 3. Mean fruit weight (MWF), commercial fruit weight (CFW), non-commercial fruit weight (NCFW), number of commercial fruits (NCF), number of non-commercial fruits (NNCF), and number of fruits with blossom end rot (NFBER) per plant as a function of the calcium application frequency and growing seasons Spring-Summer (Spr-Sum) and Summer-Fall (Sum-Fall).

\begin{tabular}{|c|c|c|c|c|c|c|}
\hline \multirow{2}{*}{$\begin{array}{c}\text { Frequency of } \\
\mathrm{CaCl}_{2}\end{array}$} & \multicolumn{2}{|c|}{ MWF (g/fruit) } & \multicolumn{2}{|c|}{ CFW (kg/plant) } & \multicolumn{2}{|c|}{ NCFW (g/plant) } \\
\hline & Spr-sum & Sum-fall & Spr-sum & Sum-fall & Spr-sum & Sum-fall \\
\hline Without & 97.4 bA & 89.6 bB & $1.2 \mathrm{cA}$ & $1.1 \mathrm{cA}$ & 750.9 aA & $576.7 \mathrm{aB}$ \\
\hline Biweekly & $101.4 \mathrm{aA}$ & $100.7 \mathrm{aA}$ & $2.5 \mathrm{aA}$ & $1.9 \mathrm{aB}$ & $241.6 \mathrm{cA}$ & $276.4 \mathrm{bA}$ \\
\hline Weekly & $100.0 \mathrm{abA}$ & $98.7 \mathrm{aA}$ & $2.1 \mathrm{bA}$ & $1.8 \mathrm{bB}$ & $358.6 \mathrm{bA}$ & $308.2 \mathrm{bA}$ \\
\hline CV (\%) & \multicolumn{2}{|c|}{6.74} & \multicolumn{2}{|c|}{14.61} & \multicolumn{2}{|c|}{33.83} \\
\hline \multirow{2}{*}{$\begin{array}{c}\text { Frequency of } \\
\mathrm{CaCl}_{2}\end{array}$} & \multicolumn{2}{|c|}{ NCF/plant } & \multicolumn{2}{|c|}{ NNCF/plant } & \multicolumn{2}{|c|}{ NFBER/plant } \\
\hline & Spr-sum & Sum-fall & Spr-sum & Sum-fall & Spr-sum & Sum-fall \\
\hline Without & $11.4 \mathrm{cA}$ & $12.2 \mathrm{cA}$ & $8.7 \mathrm{aA}$ & $7.0 \mathrm{aB}$ & $7.9 \mathrm{aA}$ & $6.1 \mathrm{aB}$ \\
\hline Biweekly & $24.3 \mathrm{aA}$ & $19.3 \mathrm{aB}$ & $2.8 \mathrm{cA}$ & $3.0 \mathrm{bA}$ & $2.1 \mathrm{cA}$ & $1.6 \mathrm{bA}$ \\
\hline Weekly & $20.7 \mathrm{bA}$ & $17.6 \mathrm{bB}$ & $4.1 \mathrm{bA}$ & $3.7 \mathrm{bA}$ & $3.5 \mathrm{bA}$ & $2.1 \mathrm{bB}$ \\
\hline CV (\%) & \multicolumn{2}{|c|}{14.03} & \multicolumn{2}{|c|}{29.87} & \multicolumn{2}{|c|}{30.3} \\
\hline
\end{tabular}

Means followed by the same lowercase letters in column and upper case in the row do not differ from each other according to the Tukey test $(P \leq 0.05)$.

from the other frequencies. For the San Vito hybrid, the lowest TNF was observed in the absence of a calcium application and the other frequencies presented statistical similarity (Tab. 4).

For the number of non-commercial fruits (NNCF) and number of fruits with blossom end rot (NFBER), the absence of a calcium application and the weekly application in the San Vito hybrid showed the greatest values. The biweekly applications resulted in a similar performance, reducing both NNCF and NFBER. For both tested hybrids, the weekly and biweekly application frequencies provided lower values of NNCF and NFBER/plant, and differed statistically from the absence of a calcium application (Tab. 4).

The hybrids produced similar fresh weights and commercial fruit yields in the absence of a calcium application. In the weekly and biweekly application frequencies, the Netuno hybrid presented superior performance when compared to San Vito. Both hybrids presented a greater FWF with a biweekly application of calcium followed by the weekly application

Table 4. Total number of fruits (TNF), number of non-commercial fruits (NNCF), number of fruits with blossom end rot (NFBER), fresh weight of fruits (FWF), non-commercial fruit weight (NCFW)/plant, and commercial fruit yield (CFY) as a function of the frequencies of calcium applications and Italian tomato hybrids.

\begin{tabular}{|c|c|c|c|c|c|c|}
\hline \multirow{2}{*}{$\begin{array}{l}\text { Frequency of } \\
\qquad \mathrm{CaCl}_{2}\end{array}$} & \multicolumn{2}{|c|}{ TNF/plant } & \multicolumn{2}{|c|}{ NNCF/plant } & \multicolumn{2}{|c|}{ NFBER/plant } \\
\hline & Netuno & San Vito & Netuno & San Vito & Netuno & San Vito \\
\hline Without & $19.3 \mathrm{cA}$ & $20.1 \mathrm{bA}$ & $6.1 \mathrm{aB}$ & $9.7 \mathrm{aA}$ & $5.1 \mathrm{aB}$ & $8.9 \mathrm{aA}$ \\
\hline Biweekly & $25.9 \mathrm{aA}$ & $23.5 \mathrm{aB}$ & $2.7 \mathrm{bA}$ & $3.1 \mathrm{cA}$ & $1.5 \mathrm{bA}$ & $2.2 \mathrm{cA}$ \\
\hline Weekly & $23.9 \mathrm{bA}$ & $22.1 \mathrm{aB}$ & $3.2 \mathrm{bB}$ & $4.6 \mathrm{bA}$ & $1.9 \mathrm{bB}$ & $3.6 \mathrm{bA}$ \\
\hline CV $(\%)$ & \multicolumn{2}{|c|}{11.66} & \multicolumn{2}{|c|}{29.87} & \multicolumn{2}{|c|}{30.3} \\
\hline \multirow{2}{*}{$\begin{array}{c}\text { Frequency of } \\
\mathrm{CaCl}_{2}\end{array}$} & \multicolumn{2}{|c|}{ FWF (kg/plant) } & \multicolumn{2}{|c|}{ NCFW (g/plant) } & \multicolumn{2}{|c|}{ CFY $\left(\mathrm{t} \mathrm{ha}^{-1}\right)$} \\
\hline & Netuno & San Vito & Netuno & San Vito & Netuno & San Vito \\
\hline Without & $1.8 \mathrm{cA}$ & $1.8 \mathrm{cA}$ & $534.5 \mathrm{aB}$ & $793.1 \mathrm{aA}$ & $36.8 \mathrm{cA}$ & $36.6 \mathrm{cA}$ \\
\hline Biweekly & $2.6 \mathrm{aA}$ & $2.3 \mathrm{aB}$ & $243.4 \mathrm{bA}$ & $274.6 \mathrm{cA}$ & $52.8 \mathrm{aA}$ & $47.1 \mathrm{aB}$ \\
\hline Weekly & $2.4 \mathrm{bA}$ & $2.1 \mathrm{bB}$ & 264.6 bB & $402.2 \mathrm{bA}$ & $48.5 \mathrm{bA}$ & $43.1 \mathrm{bB}$ \\
\hline CV (\%) & \multicolumn{2}{|c|}{11.27} & \multicolumn{2}{|c|}{33.83} & \multicolumn{2}{|c|}{11.37} \\
\hline
\end{tabular}

Means followed by the same lowercase letters in the column and upper case in the row do not differ from each other according to the Tukey test $(P \leq 0.05)$. 
and a lower FWF in the absence of calcium, differing statistically from each other (Tab. 4). The greatest CFY was observed for biweekly applications, reaching $52.8 \mathrm{t} \mathrm{ha}^{-1}$ with Netuno and $47.1 \mathrm{t} \mathrm{ha} \mathrm{a}^{-1}$ with San Vito.

For the non-commercial fruit weight (NCFW) as a function of the frequency of calcium application for the tested hybrids, the hybrid Netuno presented a lower NCFW in the absence of calcium and with a weekly application; in the biweekly application, the hybrids performed similarly. The San Vito hybrid presented a greater NCFW in the absence of calcium and a lower NCFW in the biweekly application of calcium. The Netuno hybrid exhibited a lower NCFW in the weekly and biweekly applications (Tab. 4).

The plants presented superior production in Spring-Summer when compared to summer-fall for the fresh weight of fruits and the commercial fruit yield during the different growing seasons (Tab. 5).

\section{Table 5. Fresh weight of fruits (FWF) per plant and com- mercial fruit yield (CFY) of Italian tomato hybrids as a function of the growing seasons.}

\begin{tabular}{|l|c|c|}
\hline \multicolumn{1}{|c|}{ Growing season } & FFW (kg/plant) & CFY $\left(\mathrm{t} \mathrm{ha}^{-1}\right)$ \\
\hline Spring-summer & $2.4 \mathrm{a}$ & $47.9 \mathrm{~A}$ \\
\hline Summer-fall & $2.0 \mathrm{~b}$ & $40.5 \mathrm{~B}$ \\
\hline CV(\%) & 11.27 & 11.37 \\
\hline
\end{tabular}

Means followed by the same letters do not differ according to the Tukey test $(P \leq 0.05)$.

Linearity for the equation of variable total number of fruits (TNF/plant) as a function of the boron doses was verified with the regression analysis. The Netuno hybrid showed an increase of TNF with the addition of a boron dose in the soil, while the San Vito hybrid showed a similar TNF regardless of the boron dose applied (Fig. 3A). A Linear regression was observed for the mean number of commercial fruits (NCF) as a function of the applied boron doses; an increase in the boron dose provided an increase in NCF. The dose of $4.0 \mathrm{~g}$ of boron/hole produced 18.5 commercial fruits per plant, while the non-boron application yielded 16.0 commercial fruits per plant (Fig. 3B).

Analyzing the fresh weight of fruits (FWF) per plant for different boron doses the San Vito hybrid exhibited a linear regression with an increased FWF according to increments in the boron dose. The Netuno hybrid maintained the FWF independent of the boron addition, with a mean of $2.2 \mathrm{~kg} /$ plant (Fig. 3C).

The Netuno hybrid presented a greater yield with increased boron dosages and exhibited a linear regression, while the yield of the San Vito hybrid was not influenced by the increase of boron doses. The hybrids presented a mean of $44 \mathrm{t} \mathrm{ha}^{-1}$ in the absence of boron and in the addition of $2.0 \mathrm{~g}$ boron/hole. On the other hand, with $4.0 \mathrm{~g}$ boron/hole, the Netuno hybrid presented a greater yield with a mean of $50 \mathrm{t}$ ha-1 (Fig. 3D).

For the commercial fruit weight (CFW) as a function of frequencies of calcium application for the boron doses, a low accumulation of CFW was observed in the absence of a calcium application, reaching a mean of $1.2 \mathrm{~kg} /$ plant. A linear response was observed in the weekly and biweekly applications, represented by a sharp increase in yield according to the application of boron. A higher production of commercial fruit weight was seen in the biweekly application of calcium (Fig. 3E). For the non-commercial fruit weight (NCFW), the mean yield of the three boron doses was $256.6 \mathrm{~g} /$ plant and $314.3 \mathrm{~g} /$ plant in the weekly and biweekly applications, respectively. A greater NCFW was seen in the absence of boron doses, followed by weekly and biweekly application. There were greater yields in the absence of calcium for the doses of 2.0 and $4.0 \mathrm{~g}$ boron than for weekly and biweekly applications (Fig. 3F).

The number of non-commercial fruits (NNCF) per plant as a function of boron doses and frequency of calcium application in the absence of a calcium application presented a crescent linear equation and an increase in NNCF with greater boron doses. Weekly and biweekly calcium applications were not influenced by the applied boron doses (Fig. 3G). The plants produced approximately 7.0 fruits with blossom end rot in the absence of a calcium application, followed by 2.0 and 3.0 fruits, respectively, for biweekly and weekly applications. The boron applications did not affect the availability of calcium or the incidence of blossom end rot (data not shown).

\section{DISCUSSION}

During the flowering and beginning of fruiting stage, the mean temperature was within the recommended range for the crop in both growing seasons, which according to Filgueira (2008) and Silva and Nascimento 


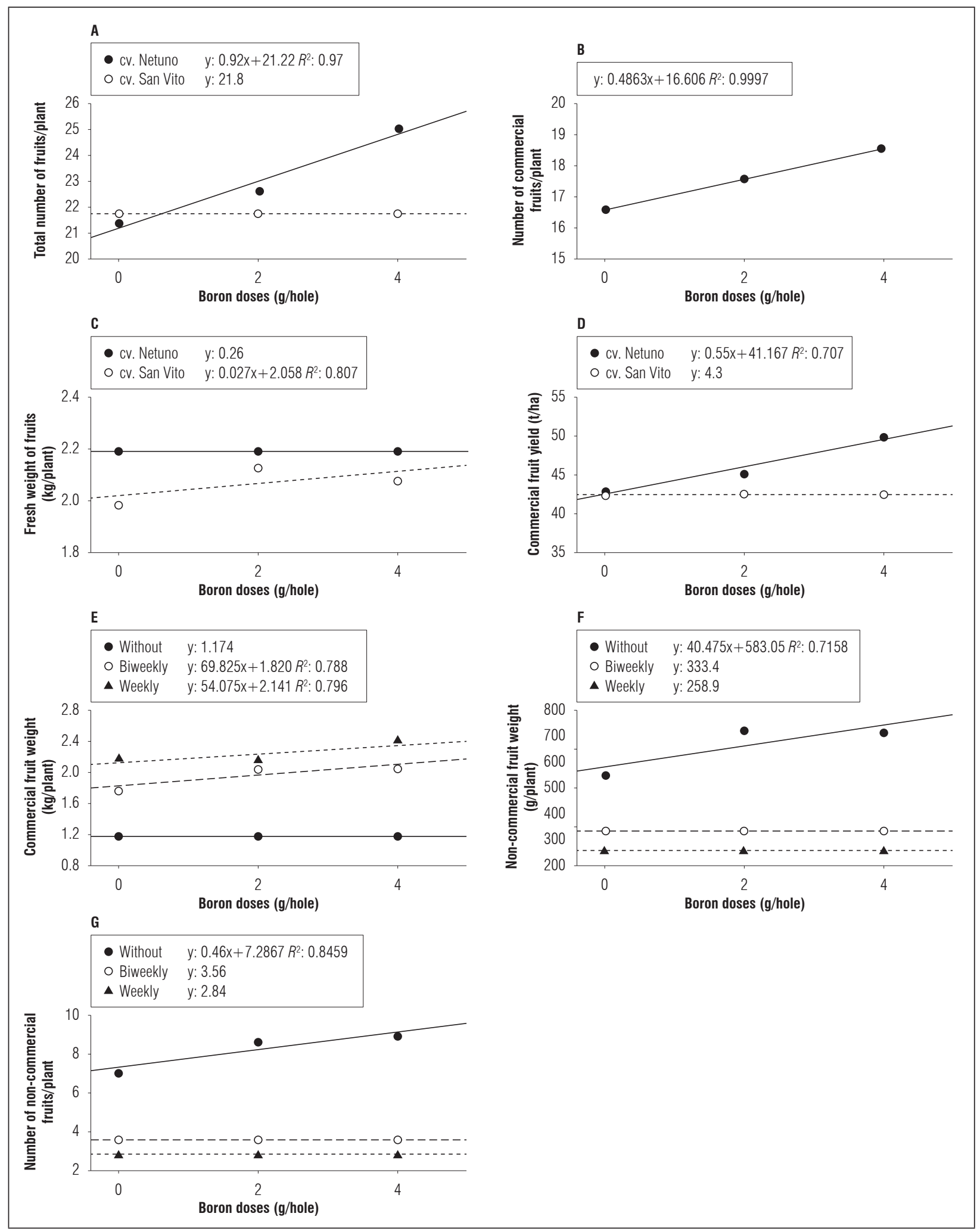

Figure 3. A. Total number of fruits/plant; B. Number of commercial fruits/plant; C. Fresh weight of fruits; D. Commercial fruit yield; E. Commercial fruit weight; F. Non-commercial fruit weight; G. Number of non-commercial fruits/plant of the Italian tomato hybrids as a function of different boron doses and frequency of calcium application. 
(2007) is 18 to $24^{\circ} \mathrm{C}$. Lower temperatures occurred during the Summer-Fall growing season, with the minimum temperature below the tolerable limit for the crop, which, according to Alvarenga (2004), is $10^{\circ} \mathrm{C}$. This event also occurred in the fruit maturation stage because, according to Filgueira (2008), the ideal air temperature is between 20 and $24^{\circ} \mathrm{C}$ in this stage.

Tomatoes are adapted to warm climates, need a long growing season and its performance is closely related to the air temperature. Metabolic processes are accelerated when temperatures are higher and metabolisms tend to decrease during colder periods (Cruz et al., 2008). When exposed to low temperatures, the species presents shorter internode lengths, decreased plant height, inhibition of fruit formation, and a generally late harvest (Filgueira, 2008).

This species requires approximately $8.4 \mathrm{MJ} \mathrm{m}^{-2} \mathrm{~d}^{-1}$ of incident solar radiation to produce the minimum quantity of photoassimilates necessary for its maintenance (Andriolo et al., 2000), while the radiation intercepted during the Spring-Summer period is considered ideal. Solar radiation and air temperature are the meteorological variables that most affect tomato growth, development, and yields (Hoogenboom, 2000). According to Andriolo et al. (2000), plants that are in full fruiting stage are more demanding of solar radiation than plants at the beginning of vegetative growth. When solar radiation levels are not enough to meet plant demand, competition from photoassimilates occurs between the vegetative parts and the fruits, reducing the rate of emission or fixation of fruits.

The Italian tomato hybrids usually present fruits with a transverse diameter of 3 to $5 \mathrm{~cm}$, as they are mainly consumed fresh and valued for the reduced weight and size (Andreuccett et al., 2005). The commercial fruit weight differed among the hybrids, with Netuno presenting better results than San Vito. The results found for the hybrid Netuno are lower than those observed by Shirahige et al. (2010), while San Vito presented a mean weight similar to the data found by Monteiro et al. (2008) and those indicated by the manufacturer. According to Embrapa (2003), the San Vito hybrid has a mean weight of 95 to 105 ; moreover, the fruit diameter and weight are considered genetic traits, explaining the differences found in the performance of the hybrids.

For the number and weight of commercial fruits per plant, the Netuno hybrid is, probably, less susceptible than San Vito to incident anomalies that can affect commercial production because San Vito is more sensitive to calcium deficiencies (Embrapa, 2003). The greater number of fruits produced by the Netuno hybrid is likely a result of its greater efficiency in fruit fixation. The data agreed with Silva et al. (2012) who evaluated Italian tomato hybrids in protected cultivation and reported that the San Vito hybrid presented a higher incidence of blossom end rot when compared to the others hybrids.

In the assessment of calcium applications in the saladette hybrid group, Silva et al. (2009) verified that calcium supply provided formation of fruits with a diameter greater than $40 \mathrm{~mm}$, whereas the absence decreased the mean diameter of the fruits, which corroborate with the results seen in the present study. The calcium applications applied to floral provided fruit production with a larger diameter in comparison to those produced in the absence of calcium.

Calcium is essential for the maintenance of plasma membrane stability (Marschner, 1986). This element, when properly supplied, provides greater fruit establishment, greater growth, and a lower incidence of physiological disorders, along with an increasing number and weight of commercial fruits. The values obtained in this study contradict the data found by Arruda Júnior et al. (2011) who evaluated the saladette hybrid group and verified that, as the calcium dose increases, a decrease in the mean weight of fruits is observed.

Among other functions, calcium acts on flower fixation, acting on pollen grain germination and pollen tube growth (Malavolta et al., 1997). The biweekly application of calcium provided a greater sugar accumulation in the fruit and greater fresh weight of fruits in relation to the absence of calcium. An over-application of calcium doses may have occurred in the weekly application, where biweekly applications had already met the nutritional requirements of the hybrids. The foliar application of $\mathrm{CaCl}_{2}(0.6 \%)+$ borax $(0.2 \%)$ resulted in the maximum plant height, branches per plant, flowers, fruits, fruit mass, yield, fruit firmness and total soluble solids and the lowest incidence of rot (Rab and Haq, 2012).

The number of fruits produced is a direct consequence of the index of fruit fixation of the plant. Contradictory data were found by Plese et al. (1997) in saladette type tomatoes, where the weekly application of $\mathrm{CaCl}_{2}$ provided a greater number of fruits per plant. 
In the Spring-Summer growing season, non-limiting solar radiation and elevated temperatures stimulated greater commercial fruit production. These factors did not adversely affect the physiological processes of the plant, and likely resulted in a greater amount of photoassimilates. This likely increase of photoassimilates in the plant provided a greater quantity of fruits per raceme, increased fruit size, and improvement in fruit quality, increasing commercial production (Caliman, 2003), as well as productivity, and production per plant. In the Spring-Summer growing season, the highest incidence of diseases was seen; this affected the maturation and the final quality of the fruits.

During the Summer-Fall growing season, a reduction in the availability of solar radiation and the occurrence of lower temperatures resulted in a reduction in the metabolism, formation of smaller fruits, slow ripening, and reduced productivity, which justifies the observed results.

The occurrence of higher temperatures in the Spring-Summer growing season was responsible for the increase in the transpiration rate and, consequently, stomata closure, decreasing the transpiratory flow; therefore, the lower absorption and translocation of calcium likely caused blossom end rot (Taiz and Zeiger, 2013). High temperatures (above $30^{\circ} \mathrm{C}$ ) can lead to physiological disorders such as fruit yellowing, poor development, and hollow fruits (Embrapa, 2003). Furthermore, Carrijo et al. (2004) verified higher values of incidence than those found in this study, varying from 8.3 to 15 fruits with blossom end rot per plant.

Blossom end rot is considered one of the most important physiological disorders in tomato. The disorder is caused by calcium deficiency in fruits and is characterized by the appearance of necrotic tissue in the distal part of the fruit (Saure, 2001). One of the recommendations to correct calcium deficiencies is by spraying, as observed by Borkowski (1984), with $0.5 \%$ calcium chloride directed at the floral stem. The control of this disorder is important because blossom end rot is one of the components that most influences the reduction of tomato productivity (Loos et al., 2008).

The yield observed in the present study can be considered adequate since the mean tomato yield in the state of Rio Grande do Sul in 2012, according to IBGE (2012), was $44.7 \mathrm{t} \mathrm{ha}^{-1}$. The data obtained in Spring-Summer growing season were above the State mean, while, in the Summer-Fall season, the yield was lower. Assessing the performance of Italian tomato in the field, Machado et al. (2007) found a mean yield of 75 and 83 t ha $^{-1}$ respectively for the Heinz 9780 and Kátia cultivars, which was greater than those found in the present study.

Although the yield in this study is considered adequate, the data were lower than those found by Machado et al. (2007) who cultivated Italian tomatoes in the field and found 28 and 32 fruits per plant respectively for the Heinz 9780 and Katia cultivars.

The proper supply of boron is of great importance because micronutrients significantly affect tomato productivity, quality, and quantity of fruits (Silva and Faria, 2004). Boron is important for pollination, fruit development, pollen tube growth, fruiting processes, and hormonal activities and has an essential role in the absorption and use of calcium (Galli et al., 2012). There is poor flowering and pollination when a boron deficiency is present, and, consequently, there are lower rates of fruit fixation in the plant, lower amount of fruits per plant, and reduced fruit sizes and a greater incidence of open loci (Silva and Faria, 2004). Higher boron leaf spray rates showed a reduction in the incidence of defects (Huang and Snapp, 2004).

The elements boron and calcium act together in fruit formation, reducing the incidence of poor fruit formation and rot. According to Ramon (1990), a deficiency or excess of boron leads to a deficiency of calcium, which has a fundamental role in cell walls. The deterioration of the membranes of fruit cells occurs especially in newly formed fruits, with a consequent loss of turgor and leakage of cellular liquid (Saure, 2001). Boron deficiencies are responsible for changes in calcium translocation in shoots and fruits. In addition, boron deficiencies can cause a decrease in calcium content for leaves which affect processes of absorption and translocation in the plant (Yamauchi et al., 1986).

An inadequate nutrient supply of calcium and boron can contribute to a reduction in yield because of lower rates of fruit production (Laviola and Dias, 2008). Values different than those found in this study were observed by Plese et al. (1998) because they were able to further reduce the occurrence of blossom end rot in tomatoes with the addition of boron and calcium. Inadequate supplies of calcium and boron contribute to a reduction in the production of commercial fruits (Laviola and Dias, 2008). 
Soil correction and supply with boron sources and sprays with calcium solution in the floral stems are fundamental for ensuring high yields.

\section{CONCLUSIONS}

The Netuno hybrid is more productive in comparison to the San Vito hybrid, but more susceptible to blossom end rot.

The growing seasons of Spring-Summer and Summer-Fall can be recommended for Italian tomato cultivation in Rio Grande do Sul because they acheive yields close to the statewide means.

The frequency of the biweekly applications of $0.6 \%$ $\mathrm{CaCl}_{2}$ is the best option for fertilizer management when attempting to improve yields and maintain a lower number of fruits with an incidence of blossom end rot.

Increment doses of boron up to $4 \mathrm{~g} /$ hole increased the yields of the Italian tomato hybrids.

\section{ACKNOWLEDGMENTS}

The authors would like to thank the Coordenação de Aperfeiçoamento de Pessoal de Nível Superior (CAPES) for its scholarship.

Conflict of interests: the manuscript was prepared and reviewed with the participation of the authors, who declare that there exists no conflict of interest that puts in risk the validity of the presented results.

\section{BIBLIOGRAPHIC REFERENCES}

Alvarenga, M.A.R. 2004. Origem, botânica e descrição da plantas. In: Alverenga, M.A.R. (ed.). Tomate: produção em campo, em casa de vegetação e em hidroponia. UFLA Lavras-MG, Brazil.

Alvares, C.A., J.L. Stape, P.C. Sentelhas, J.L.M. Gonçalves, and G. Sparovek. 2014. Köppen's climate classification map for Brazil. Meteorol. Zeitschr. 22 (6), 711-728. Doi: 10.1127/0941-2948/2013/0507

Andreuccett, C., M.D. Ferreira, A.S.D. Gutierrez, and M. Tavares. 2005. Caracterização da comercialização de tomate de mesa na CEAGESP: perfil dos atacadistas. Hortic. Bras. 23, 324-328. Doi: 10.1590/ S0102-05362005000200033

Andriolo, J.L., L. Ludke, T.S. Duarte, and E.C. Skrebsky. 2000. Posição dos frutos e seu efeito na repartição da matéria seca da planta do tomateiro. Ciênc. Rural 30 (2), 235-240. Doi: 10.1590/S0103-84782000000200007

Arruda Júnior, S.J., E.B. Neto, L.P. Barreto, and L.V. Resende. 2011. Podridão apical e produtividade do tomateiro em função dos teores de cálcio e amônio. Rev. Caatinga 24 (4), 20-26.

Borkowski, J. 1984. Study on the calcium uptake dynamic by tomato fruits and blossom end rot control. Acta Hortic. 145, 222-229. Doi: 10.17660/ ActaHortic.1984.145.23

Bresolin, M. 2010. O cultivo do tomate indústria na região da serra do nordeste do Estado do Rio Grande do Sul Porto Alegre. Boletim técnico. FEPAGRO, UCS, Caxias do Sul-RS, Brazil.

Caliman, F.R.B. 2003. Produção e qualidade de frutos de genótipos de tomateiro em ambiente protegido e no campo. Tese de mestrado. Universidade Federal de Viçosa, Viçosa-MG, Brazil.

Carrijo, O.A., M.C. Vidal, N.V.B. Reis, R.B. Souza, and N. Makishima. 2004. Produtividade do tomateiro em diferentes substratos e modelos de casas de vegetação. Hortic. Bras. 22(1), 5-9. Doi: 10.1590/ S0102-05362004000100001

Cruz, J.C., I.A. Pereira Filho, R.C. Alvarenga, M.M. Gontijo Neto, M.F. Oliveira, and W.J.R. Matrangolo. 2008. Manejo da cultura do milho. In: Cruz, J.C. (ed.). Cultivo do milho. 4 ed. Embrapa Milho e Sorgo, Sete Lagoas-MG, Brazil.

Dechen, A.R. and G.R Nachtigall. 2007. Elementos requeridos à nutrição de plantas. In: Novais, R.F., V.V.H. Alvarez, N.F. Barros, R.L.F. Fontes, R.B. Cantarutti, and J.C.L. Neves (eds.). Fertilidade do solo. Sociedade Brasileira de Ciência do Solo, Viçosa-MG, Brazil.

Embrapa (Empresa Brasileira de Pesquisa Agropecuária). 2013. Sistema brasileiro de classificação de solos. $3^{\mathrm{a}} \mathrm{ed}$. Centro Nacional de Pesquisa de Solos, Rio de Janeiro-RJ, Brazil.

Embrapa (Empresa Brasileira de Pesquisa Agropecuária). 2003. Cultivo de tomate para industrialização. Embrapa Hortaliças, Centro Nacional de Pesquisa de Hortaliças, Brasilia-DF, Brazil.

Filgueira F.A.R. 2008. Novo Manual de olericultura: agrotecnologia moderna na produção e comercialização de hortaliças. UFV, Viçosa-MG, Brazil.

Galli, J.A., M.C.A. Palharini, I.H. Fischer, M.D. Michelotto, and A.L.M. Martins. 2012. Boro: efeito na produção e qualidade de frutos de diferentes variedades de manga. Pesqu. Tecnol. 9(2).

Giordano, L.B., L.S. Boiteux, J.B.C. Silva, and O.A. Carrijo. 2005. Seleção de linhagens com tolerância ao calor em germoplasma de tomateiro coletado na região Norte do Brasil. Hortic. Bras. 23, 105-107. Doi: 10.1590/ S0102-05362005000100022 
Greenleaf, W.H. and F. Adams. 1969. Genetic Controlo f blossomend-rot disease in tomatoes through calcium metabolism. J. Amer. Soc. Hort. Sci. 94, 248-250.

Hoogenboom, G. 2000. Contribution of agrometeorology to the simulation of crop production and its application. Agric. For. Meteorol. 103 (1), 137-157. Doi: 10.1016/S0168-1923(00)00108-8

Huang, J.S. and S.S. Snapp. 2004. The effect of boron, calcium, and surface moisture on shoulder check, a quality defect in fresh-market tomato. J. Amer. Soc. Hort. Sci. 129, 599-607.

IBGE. 2012. Instituto Brasileiro de Geografia Estatística; Cepagro (Centro de Estudos e Promoção da Agricultura de Grupo). Levantamento Sistemático da Produção Agrícola. Rio de Janeiro-RJ, Brazil.

Iglesias, M.J., J. García-López, J.F. Collados-Luján, F. López-Ortiz, M. Díaz, F. Toresano, and F. Camacho. 2015. Differential response to environmental and nutritional factors of high-quality tomato varieties. Food Chem. 176, 278-287. Doi: 10.1016/j. foodchem.2014.12.043

Laviola, B.G. and L.A. Santos Dias. 2008. Teor e Acúmulo de nutrientes emfolhas e frutos de pinhão-manso. Rev. Bras. Ciênc. Solo 32(5), 1969-1975. Doi: 10.1590/ S0100-06832008000500018

Loos, R.A., D.J.H. Silva, P.C.R. Fontes, and M.C. Picanço. 2008. Identificação e quantificação dos componentes de perdas de produção do tomateiro em ambiente protegido. Hortic. Bras. 26(2), 281-286. Doi: 10.1590/ S0102-05362008000200031

Machado, A.O., M.A.R. Alvarenga, and C.E.T. Florentino. 2007. Produção de tomate italiano (saladete) sob diferentes densidades de plantio e sistemas de poda visando ao consumo in natura. Hortic. Bras. 25, 149-153. Doi: 10.1590/S0102-05362007000200004

Malavolta, E., G.C. Vitti, and S. De Oliveira. 1989. Avaliação do estado nutricional das plantas: Princípios e aplicações. Associação Brasileira para Pesquisa da Potassa e do Fosfato, Piracicaba-SP, Brazil.

Malavolta, E., G.C. Vitti, and S.A. Oliveira. 1997. Avaliação do estado nutricional das plantas: princípios e aplicações. Associação Brasileira para Pesquisa da Potassa e do Fosfato, Piracicaba-SP, Brazil.

MAPA. 2015. Tomate. In: http://www.agricultura.mg.gov. br/images/documentos/perfil_tomate_mar_2015[1]. pdf; consulted: Abril, 2016.

Marschner, H. 1986. Mineral nutrition of higher plants. Academic Press, London, UK.

Monteiro, C.S., M.E. Balbi, O.G. Miguel, P.T.P.S. Penteado, and S.M.C. Haracemiv. 2008. Nutritional quality the antioxidants of the tomato "Italian type". Alim. Nutr. 19, 25-31.

Plese, L.P.M., C.S. Tiritan, E.I. Yassuda, L.I. Prochnow, J.E. Corrente, and S.C. Mello. 1997. Efeitos das aplicações de cálcio e de boro na ocorrência de podridão apical e produção de tomate em estufa. In: XXVI Congresso Brasileiro de Ciência do Solo.
Plese, L.P.M., C.S. Tiritan, E.I. Yassuda, L.I. Prochnow, J.E. Corrente, and S.C. Mello. 1998. Efeitos das aplicações de cálcio e de boro na ocorrência de podridão apical e produção de tomate em estufa. Sci. Agríc. 55(1), 144148. Doi: 10.1590/S0103-90161998000100023

Rab, A. and I.U. Haq. 2012. Foliar application of calcium chloride and borax influences plant growth, yield, and quality of tomato (Lycopersicon esculentum Mill.) fruit. Turk. J. Agric. For. 36, 695-701.

Ramon, A.M., R.O. Carpena-Ruiz, and A. Garate. 1990. The effects of short term deficiency of boron on potassium, calcium and magnesium distribution in leaves and roots of tomato (Lycopersicon esculentum) plants. Dev. Plant Soil Sci. 21, 287-290. Doi: 10.1007/978-94-009-0585-6_48

SAS Institute. 2002. SAS user's guide: statistics. Version 9.0. Cary, NC, USA.

Saure, M.C. 2001. Blossom-end rot of tomato (Lycopersicon esculentum Mill.) - a calcium- or a stess-related disorder? Sci. Hortic. 90(3), 193-208. Doi: 10.1016/ S0304-4238(01)00227-8

Schwarz, K., J.T.V., Resende, A.P. Preczenhak, J.T. Paula, M.V. Faria, and O.M. Dias. 2013. Desempenho agronômico e qualidade físico-química de híbridos de tomateiro em cultivo rasteiro. Hortic. Bras. 31, 410-418. Doi: 10.1590/S0102-05362013000300011

Shirahige, F.H., A.M.T. Melo, L.F.V. Purquerio, C.R.L. Carvalho, and P.C.T. Melo. 2010. Produtividade e qualidade de tomates Santa Cruz e Italiano em função do raleio de frutos. Hortic. Bras. 28, 292-298. Doi: 10.1590/S0102-05362010000300009

Silva, D.J. and C.M.B. Faria. 2004. Nutrição, calagem e adubação. In: Mouco, M.A.C. (ed.). Cultivo da mangueira. Embrapa Semi-Árido, Petrolina-PE, Brazil.

Silva, G.P., F.V. Resende, R.B. Souza, J.O. Albuquerque, M.C. Vidal, and J.M.M Sousa. 2012. Desempenho agronômico de híbridos de tomate italiano sob cultivo protegido em solo com cobertura viva de amendoim forrageiro no sistema orgânico de produção. Hortic. Bras. 30, S8389-S8394.

Silva, M.W., C.J. Jadoski, E.O. Ono, and R. Goto. 2009. Cálcio, boro e reguladores vegetais na fixação de frutos em tomateiro. Pesqu. Aplicada Agrotecnol. 2(3), 103-112.

Silva, S.C. and D.J. Nascimento. 2007. Avanços na pesquisa com plantas forrageiras tropicais em pastagens: características morfofisiológicas e manejo do pastejo. Rev. Bras. Zootecnia 36, 121-138. Doi: 10.1590/ S1516-35982007001000014

Taiz, L. and E. Zeiger. 2013. Fisiologia vegetal. $5^{\text {a }}$ ed. Artmed, Porto Alegre-RS, Brazil.

Yamauchi, T., T. Hara, and Y. Sonida. 1986. Distribution of calcium and boron in the pectin fraction of tomato leaf cell wall. Plant Cell Physiol. 27(4), 729-732. Doi: 10.1093/oxfordjournals.pcp.a077155 